\title{
"Management and comprehensive assessment of the probability of bankruptcy of Ukrainian enterprises based on the methods of fuzzy sets theory"
}

\begin{tabular}{|c|c|}
\hline \multirow{9}{*}{ AUTHORS } & Serhii Kozlovskyi (D https://orcid.org/0000-0003-0707-4996 \\
\hline & $\mathbb{R}$ http://www.researcherid.com/rid/P-3856-2017 \\
\hline & Andrii Butyrskyi (D https://orcid.org/0000-0002-3225-7017 \\
\hline & $\mathbb{R}$ http://www.researcherid.com/rid/T-6709-2018 \\
\hline & Boris Poliakov \\
\hline & Antonına Bobkova (D nttps://0rcid.org/0000-0002-0834-/514 \\
\hline & Ruslan Lavrov (D) https://orcid.org/0000-0002-9655-4467 \\
\hline & $\mathbb{R}$ http://www.researcherid.com/rid/l-1733-2014 \\
\hline & Natalya Ivanyuta (D https://orcid.org/0000-0001-9177-9280 \\
\hline ARTICLE INFO & $\begin{array}{l}\text { Serhii Kozlovskyi, Andrii Butyrskyi, Boris Poliakov, Antonina Bobkova, Ruslan } \\
\text { Lavrov and Natalya Ivanyuta (2019). Management and comprehensive } \\
\text { assessment of the probability of bankruptcy of Ukrainian enterprises based on } \\
\text { the methods of fuzzy sets theory. Problems and Perspectives in Management, } \\
\text { 17(3), 370-381. doi:10.21511/ppm.17(3).2019.30 }\end{array}$ \\
\hline DOI & http://dx.doi.org/10.21511/ppm.17(3).2019.30 \\
\hline RELEASED ON & Thursday, 19 September 2019 \\
\hline RECEIVED ON & Thursday, 08 August 2019 \\
\hline \multirow[t]{2}{*}{ ACCEPTED ON } & Wednesday, 04 September 2019 \\
\hline & $((\mathrm{ccc}) \mathrm{EY}$ \\
\hline LICENSE & $\begin{array}{l}\text { This work is licensed under a Creative Commons Attribution } 4.0 \text { International } \\
\text { License }\end{array}$ \\
\hline JOURNAL & "Problems and Perspectives in Management" \\
\hline ISSN PRINT & $1727-7051$ \\
\hline ISSN ONLINE & $1810-5467$ \\
\hline PUBLISHER & LLC "Consulting Publishing Company "Business Perspectives" \\
\hline FOUNDER & LLC "Consulting Publishing Company "Business Perspectives" \\
\hline
\end{tabular}

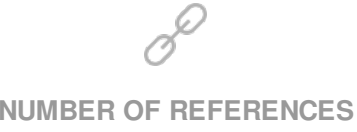

32
NUMBER OF FIGURES

2
NUMBER OF TABLES

3

(C) The author(s) 2021. This publication is an open access article. 


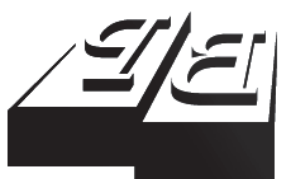

BUSINESS PERSPECTIVES

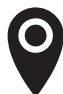

LLC "CPC "Business Perspectives" Hryhorii Skovoroda lane, 10, Sumy, 40022, Ukraine

www.businessperspectives.org

Received on: $8^{\text {th }}$ of August, 2019 Accepted on: $4^{\text {th }}$ of September, 2019

(C) Serhii Kozlovskyi, Andrii Butyrskyi, Boris Poliakov, Antonina Bobkova, Ruslan Lavrov, Natalya Ivanyuta, 2019

Serhii Kozlovskyi, D.Sc. (Economics), Professor, Faculty of Economics, Department of Entrepreneurship, Corporate and Spatial Economics, Vasyl' Stus Donetsk National University, Ukraine.

Andrii Butyrskyi, D.Sc. (Law), Professor, Yuriy Fedkovych Chernivtsi National University, Ukraine.

Boris Poliakov, D.Sc. (Law), Professor, Yaroslav Mudryi National Law University, Law and Management Institute, Kyiv, Ukraine.

Antonina Bobkova, D.Sc. (Law), Professor, Vasyl' Stus Donetsk National University, Ukraine.

Ruslan Lavrov, D.Sc. (Economics), Associate Professor, Chernihiv National University of Technology, Ukraine.

Natalya Ivanyuta, D.Sc. (Law), Associate Professor, Donetsk Law Institute of the Ministry of Internal Affairs of Ukraine, Ukraine.

\section{(c) (i)}

This is an Open Access article, distributed under the terms of the Creative Commons Attribution 4.0 International license, which permits unrestricted re-use, distribution, and reproduction in any medium, provided the original work is properly cited.
Serhii Kozlovskyi (Ukraine), Andrii Butyrskyi (Ukraine), Boris Poliakov (Ukraine), Antonina Bobkova (Ukraine), Ruslan Lavrov (Ukraine), Natalya Ivanyuta (Ukraine)

\begin{abstract}
Managing and evaluating the probability of bankruptcy of Ukrainian enterprises is one of the most complex and relevant problems of the economy and management. In the context of Ukraine's integration into the international space, there is an arising issue of assessing the bankruptcy of Ukrainian enterprises that meets international financial standards and allows administering this process. A qualitative assessment of the bankruptcy of an enterprise is possible only using artificial intelligence methods - the fuzzy sets method, which allows including qualitative and quantitative indicators to the model for assessing bankruptcy of enterprises in Ukraine. The aim of the article is to improve the existing method for assessing the probability of bankruptcy of Ukrainian enterprises on the basis of the fuzzy sets method, which will include indicators of international financial reporting and allow more efficient administration and management of this process. The subject of the research is the process of formalizing the method of the enterprise bankruptcy assessment in accordance with the indicators of International Financial Reporting Standards. The study offers a mechanism for a comprehensive assessment of the probability of bankruptcy of Ukrainian enterprises with the use of the methods of fuzzy sets, which is based on international financial indicators: current ratio, payable turnover ratio, equity turnover ratio, return on assets, equity-to-debt ratio. The mechanism allows quickly managing bankruptcy conditions. In order to administer the economic activity of the bankrupt enterprises, based on the theory of a fuzzy sets, a system of enterprises management takes into account the international financial reporting.
\end{abstract}

\section{Keywords}

administration, bankruptcy, enterprise, fuzzy sets theory, financial indicators, international financial reporting, management, decision support system

\section{JEL Classification $\quad \mathrm{C} 60, \mathrm{G} 33, \mathrm{O} 16$}

\section{INTRODUCTION}

One of the pressing problems associated with strategic management and planning is the financial condition analysis and assessment of the enterprise bankruptcy risk. Timely identification of possible bankruptcy signs allows management to take urgent measures to correct the financial condition and reduce the risk of bankruptcy.

Economic instability, the volatility of the business environment, the increase in the number of economic crises have a huge impact on the financial stability and sustainability of organizations of various industries and forms of ownership. In Ukraine, an increasing number of organizations are becoming unable to meet their obligations, which may lead to bankruptcy. For an enterprise, the ability to assess its solvency 
and determine the degree of threat of bankruptcy, as well as the onset of other financial risks, is vital. This problem is becoming very relevant in modern society.

Since the degree of Ukraine's participation in globalization and economic integration has increased sharply in recent years, global economic processes have a negative impact on the country's inner processes, which greatly complicates the work of financial services of domestic enterprises in the framework of monitoring bankruptcy risk. At the same time, a flexible financial management system at an enterprise must promptly respond to any changes occurring in its activities, which is especially important in conditions of economic instability and is almost impossible without the use of bankruptcy risk assessment methods with high accuracy and a long forecast horizon. At the same time, the specific conditions of the Ukrainian economy make people question the appropriateness of applying a number of bankruptcy risk assessment methods developed by both Ukrainian and foreign scientists, which necessitates further research in this area.

Currently, there are several generally accepted methods and techniques for assessing bankruptcy risk. The most famous and widely used one is the methodology of Professor Altman (Altman, 1968). This methodology has several disadvantages, and its application to the Ukrainian economy faces certain difficulties. Therefore, in recent years, alternative approaches and methods have been developed to take into account the specifics of analysis and decision-making under conditions of uncertainty. These include the tools of fuzzy sets and fuzzy neural networks.

Recently, automated intelligent express assessment systems have been widely used for bankruptcy assessment. These systems enable quick determination of the enterprise's condition, making preliminary conclusions and general recommendations for further actions. Nonetheless, the existing rapid assessment systems do not take into account the indicators of International Financial Reporting Standards. Moreover, they are not able to consider the qualitative and quantitative indicators simultaneously. This is a major drawback of existing bankruptcy assessment systems. This research is devoted to solving this issue.

\section{LITERATURE REVIEW}

In economic literature and the economic dictionary of Zavadskyi, Osovska, and Yushkevych (2006), bankruptcy is characterized as debt insolvency, the refusal of an entrepreneur to pay his debt obligations due to lack of funds. Economists consider bankruptcy as an instrument for the withdrawal of business entities from a crisis financial and economic situation, as the basis of the bankruptcy itself is the specific legal and economic actions. In this regard, bankruptcy is compared with a surgical operation. On the one hand, it is rather radical and dangerous measure, which is used only in extreme cases when all conservative methods of treatment proved ineffective. On the other hand, sometimes it is the only possible way to recover, the last chance to overcome a serious distress.

In Ukraine, the mechanism of the enterprises bankruptcy was established after the Verkhovna
Rada adopted the Law "On Bankruptcy", which took effect on July 1, 1992. In 2018, the Verkhovna Rada of Ukraine adopted the Code of Ukraine on Bankruptcy Procedures, which will take effect on October 21, 2019 (Code of Ukraine on Bankruptcy Procedures, 2018). In accordance with this Law, the concept of "bankruptcy" recognized by an economic court is the insolvency of the debtor to resume his solvency and satisfy the claims of the court recognized by the creditors no other than through the application of the liquidation procedure.

The current bankruptcy threat factors classification is offered by Ligonenko (2016) who proposes to divide the factors of the emergence of the bankruptcy threat into the following groups: the place of emergence of crisis factors; the degree of interdependence; the degree of influence; the time of action; the consequences of the manifestation of crisis factors. 
For the assessment of bankruptcy of Ukrainian enterprises, Andrushchak (2004) suggests to use a model based on comparing the actual values of financial indicators of a particular enterprise with their normative values. Still, such model does not provide a complete assessment of the possible state of the enterprise bankruptcy.

For compiling a model for bankruptcy assessment perform an integral score assessment, Dontsova and Nikiforova (2015) of financial sustainability of enterprises based on the division of the financial state into certain classes.

For rapid bankruptcy assessment, Sayfullin and Kadykov (2003) suggest to use a rating number, which consists of the own funds ratio; ratio of current liquidity; coefficient of turnover of own capital; the management coefficient and the return on equity ratio.

The most up-to-date method for the enterprises financial condition evaluating is the theory of fuzzy sets. Application of the theory of fuzzy sets for solving the problem of economic evaluation is provided in the papers by S. Kozlovskyi, Mazur, Vdovenko, Shepel, and V. Kozlovskyi (2018). Theory of fuzzy sets (Zadeh, 1965) allows to operate both qualitative and quantitative indicators, to form a system of artificial intelligence and to develop predictions of the level of rating assessment. The theory of fuzzy sets is an innovative mathematics that should be used to solve the research problem.

Well-known financial analysts Beaver and Manegold (1975) offered their own system of the indicators to assess bankruptcy. They proposed to explore the trend indicators for the assessment of bankruptcy. One of their conclusions is that both in the short in the and long term, the best forecast is based on the ratio of cash flows to the amount of debt, the coefficient of the structure of capital, and the coefficient of liquidity. The worst indicator for forecasting is the coefficient of turnover.

For assessing the risk of bankruptcy and enterprises' creditworthiness, discriminant factor models of well-known Western economists Altman (1968), Toffler and Tishaw (1977), Beermann (1976) are widely used. Models have been devel- oped using multidimensional discriminant analysis. However, it should be noted that the use of such models for Ukrainian enterprises requires great precautions. Testing of Ukrainian enterprises according to these models showed that they are not suitable for assessing the risk of bankruptcy in this case. It is due to the fact that they do not take into account the specifics of the post-Soviet space, which include:

- imperfection of the Ukrainian methodology for revaluation of fixed assets. Thus, old and depreciated funds are given the same value as the new ones. It leads to the situation, in which the share of own capital unreasonably increases when the funds are revalued. Ratio of own and borrowed capital is becoming unrealistic;

- high tax deductions. To avoid paying taxes the majority of Ukrainian companies declare too low profits from their activities, or even losses.

The solution here is to develop own models for each industry, which would consider the specifics of Ukrainian reality. Moreover, these models should be tested every year on new samples to clarify their discriminant strength.

Obradović et al. (2018) have developed logistic regression (LR) model to predict insolvency of a company in the Republic of Serbia. Different users of financial information might obtain preliminary information on whether there is a possibility that the company will not continue operating under the assumption of going concern (a continuity of business operations). This LR model uses the following groups of indicators: liquidity ratios, leverage ratios, activity ratios, economy ratios, profitability ratios and others. The disadvantage of this model is the lack of analysis of international financial statements of companies.

$\mathrm{Yu}$ and $\mathrm{He}$ (2018) have developed a model 'Probit and Logit', which depicts how firm size, industry characteristics, equity structure, and debt structure determine firms' bankruptcy resolutions.

Serrano-Cinca et al. (2014) developed a bankruptcy assessment model based on partial least squares path modelling (PLS-PM) and logistic regression (Kim, 2011). This model does not include indica- 
tors of international financial statements and cannot be used in practice.

Gavurova et al. (2017) in their study focused on the assessment of four bankruptcy prediction models: Altman model (1984), Ohlson model (1980), indexes IN01 and IN05 that were validated on the sample of 700 Slovak companies. As a result of the study, it was proved that the Altman (1984) model is not highly efficient for assessing the bankruptcy of enterprises.

Several discriminant multi-factor models were developed to assess bankruptcy of enterprises in Ukraine. Most well-known among them are the model by Tereshenko (2003) and the model by Matviychuk (2013).

The model by Matviychuk (2013) deserves particular attention, because its use gives more reliable results. The first major step in the development of the model was the choice and justification of the indicators system. The algorithm for forming the set of most significant factors consisted of the following steps:

- the Ukrainian enterprises financial statements analysis for the input data availability for the respective coefficients calculation (for example, most enterprises do not use the funds raised, which does not allow to calculate debt recovery ratios, the concentration of borrowed funds and the ratio of borrowed and own funds);

- choice of indicators that are suitable to draw conclusions about the enterprise financial condition;

- verification of indicators for multicollinearity;

- the final choice of indicators, that have at the same time maximum difference between the mean values for the enterprises of different groups and minimal intragroup variance.

According to the algorithm, such indicators include: asset mobility ratio, accounts payable turnover, equity turnover, ratio of return on assets, ratio of the availability of own working capital, ratio of concentration of debt capital, ratio of debt to equity.
Despite the fact that in the above model (Matviychuk, 2013) the author chose and substantiated the most informative indicators for Ukrainian enterprises, their main disadvantage is that not all indicators have analogues in the International Financial Reporting Standards. In addition, the same financial indicators may be called differently in different sources, or the same name may imply different formulae. Hence, the purpose here is to select only those basic indicators that coincide with the indicators of International Financial Reporting Standards.

\subsection{Aims}

The aim of the article is to improve the existing method for assessing the probability of bankruptcy of Ukrainian enterprises on the basis of the fuzzy sets method, which will include indicators of International Financial Reporting Standards and allow more efficient administration and management of this process.

\section{RESEARCH OBJECTIVE AND METHODOLOGY}

Methodology used to improve the method of the enterprise bankruptcy assessment includes sequence of steps:

1. Analysis of each financial indicator from the Matviychuk model (Matviychuk, 2013) for compliance with International Financial Reporting Standards. The advantages of this model are the following: it has a set of input factors that cover all major groups of financial and economic performance of enterprises, it has a high ability to predict bankruptcy and lack of multicollinearity. If the analyzed indicator does not comply with the International Financial Reporting Standards, it is necessary to find its equivalent and justify the expediency of its use from the point of view of Ukrainian legislation.

The result of this step is a system of indicators for assessment of the enterprise bankruptcy probability.

2. The definition of normative values for system of indicators, the output beyond which points 
to a high probability of the enterprise bankruptcy. If a universal normative value for indicators can be defined, then a model for an assessment of the enterprise bankruptcy probability is created in the form of discriminatory function. If the indicators are inaccurate and ambiguous, depending on many different factors, such as industry, season and so on, then it is necessary to formalize them using intellectual analysis methods.

The result of this step is a linguistic recognition of bankruptcy risk based on the value of each financial indicators of bankruptcy risk assessment.

3. Visualization of the calculations for the best formalizing of expert's ideas about the probability of the enterprise bankruptcy. It allows to transform the language of words into a language of quantitative assessments. The result can be a graph or a matrix of normalized values of indicators for assessment of the conditional enterprise bankruptcy probability.

4. Building the structure of decision support system for the probability of bankruptcy of the enterprise by means of fuzzy set theory.

\section{RESULTS}

Bankruptcy assessment is the system of targeted financial analysis, aimed at identifying parameters of the enterprise's crisis development (Sharapov \& Kaidanovich, 2012). At its core, the bankruptcy assessment is an analysis of problems arising during the operation of the enterprise that can cause negative consequences. The main task of the bankruptcy assessment is creation of an analytical basis for solving problems that appear during the life of the enterprise. The process of bankruptcy assessment should be considered as a system of research that gives the opportunity to form the necessary conclusions regarding the state of the enterprise, and possible ways out of the crisis.

Bankruptcy is assessed on the basis of factor analysis and forecasting methods. In world practice, various economic and mathematical models are used to predict the enterprise's stability, to choose its financial strategy, and to determine the risk of bankruptcy. The basis of these methods is the calculation of financial ratios.

According to the Matviychuk model, the first indicator is the asset mobility ratio.

The asset mobility ratio is calculated as the ratio of current assets and non-current assets. Mobility is the ability of assets to go from one form to another. High mobility means that the enterprise will be able to change the structure of assets in a short period of time. This concept is associated with liquidity that means the conversion rate into cash without loss of value (Yousuf et al., 2019).

According to International Financial Reporting Standards, almost all liquidity indicators in the denominator have short-term liabilities. The difference lies in the fact that, while the liquidity indicators measure the enterprise's ability to meet current liabilities, the asset mobility indicator shows the enterprise's ability to adapt to the external influence of the market and perform flexible activities.

In general, the enterprise converts its current assets into cash, and these funds are already used to cover obligations. It means that assessing the enterprise's liquidity and capacity to pay can be done by comparing these elements of the balance sheet. The current ratio does precisely that.

The current ratio is a liquidity ratio that measures a company's ability to pay short-term obligations or those due within one year. The current ratio is calculated by dividing current assets by current liabilities.

So, to conform to the International Financial Reporting Standards, the asset mobility ratio indicator should be changed to current ratio.

The next indicator is the accounts payable turnover. It indicates the number of turnovers that made payables during the year. The result of the calculation shows how many times the enterprise has paid its obligations to suppliers, contractors, etc. during the period. The Matviychuk model proposes to calculate this indicator as a ratio of net income from sales to current liabilities. 
According to International Financial Reporting Standards, the formula for the accounts payable turnover ratio is as follows:

Payable Turnover ratio $=$ Total Purchases $/$ (Average Accounts Payable).

In some cases, cost of goods sold, or net credit purchases are used in the numerator instead of Total Purchases. Average accounts payable is the sum of accounts payable at the beginning and the end of an accounting period, divided by 2 .

Therefore, for calculating payable turnover ratio it is advisable to use a ratio of Total Purchases/ (Average Accounts Payable), because this formula largely corresponds to the essence of the indicator.

Equity turnover is an indicator of business activity. It demonstrates the management efficiency of the company's equity. The ratio is calculated as the ratio of revenue (or net income) to the average annual amount of equity. The Matviychuk model offers a similar formula. Thus, the calculation of equity turnover corresponds to International Financial Reporting Standards. The high value of equity turnover indicates the effective use of the owners' capital. Ratio should be considered in the dynamics, as well as compared with the values of direct competitors in the industry.

The next one is ratio of return on assets, or ratio of payback period, as it is named in Ukrainian financial reporting. In the Matviychuk model it is offered to calculate it as a ratio of balance to net sales. During the period when the assets of the enterprise pay off themselves, net profit equal to the amount of assets used is generating. It is calculated as the ratio of the average annual value of assets to the amount of net profit. This indicator refers to a group of profitability indicators and shows overall effectiveness. The reverse indicator is return on assets (ROA). This indicator is widely used in International Financial Reporting Standards calculated by dividing an enterprise's net income by total assets. It is proposed to use the most common ratio ROA.

The indicators of financial stability include the ratio of the availability of own working capital, ratio of concentration of debt capital and ratio of debt to equity.
Ratio of the availability of own working capital is an indicator of the enterprise's ability to finance operating capital at the expense of its working capital. The value of the indicator shows the share of own current assets in the amount of current assets. While usually the indicator is calculated as the ratio of own working capital to current assets, Matviychuk model suggests determining its own working capital as the difference between current assets and current liabilities.

Ratio of concentration of debt capital indicates the level of financial instruments use or borrowed capital in order to increase the potential return on investment. For a company where the borrowed capital is significantly higher than its own, the level of leverage is high. Ratio of concentration of debt capital is calculated by dividing the current and long-term liabilities into the amount of assets. The model offers a similar formula.

Ratio of debt to equity shows the extent to which enterprise assets are formed at the expense of equity, and how much the enterprise is independent of external sources of financing.

The most important ratio used to evaluate an enterprise's financial leverage is debt-to-equity ratio. The debt-to-equity $(\mathrm{D} / \mathrm{E})$ ratio is calculated by dividing a company's total liabilities by its shareholder equity. It means that above ratios can be replaced by the debt-to-equity ratio.

Thus, to assess the enterprise bankruptcy probability, it is offered to use the following indicators: current ratio, payable turnover ratio, equity turnover ratio, return on assets, debt-to-equity ratio.

It is assumed that for the assessment of enterprise bankruptcy probability all indicators are of equal importance.

Thus, the proposed system of indicators for assessment of the enterprise bankruptcy probability, on the one hand, evaluates various aspects of the Ukrainian enterprises business and financial life without duplicating each other, and, on the other hand, fully complies with International Financial Reporting Standards. 
The next step is the definition of indicators limits. Going beyond them leads to a high probability of the enterprise's bankruptcy.

In Ukraine, normative value for the current ratio is within the 1-3, but the value of 2-3 is more desirable (Davidova \& Belikov, 1999). Current ratio below normative indicates the problem of ability to pay, because current assets are not enough to respond to current liabilities. From the standpoint of owners and management, the current ratio above normative value is a sign of inefficient asset structure. More precise conclusions may be formed on the asset analysis. It should be noted that the optimal value of the current ratio is often conditional and depends on the scope of activity, seasonal factor, terms of the cooperation agreement with suppliers, etc.

Payable turnover ratio can vary in the range from 4.8 to 12. It differs depending on the type of enterprise's activity. The best approach here is to compare the payables management current situation with competitors. It is also worth considering the dynamics and assessing its change over the time period.

The normative value of equity turnover ratio is not established. Usually it is considered in dynamics and compared with the values of competitors in the industry. The equity turnover increase over the period suggests optimization of the enterprise's work in this area.

Moreover, there is no single normative value for the return on assets. It is necessary to analyze it in dynamics, comparing the values with both different years and competitors that have the same size of the sum of assets or income. The higher the indicator, the more effective the management process, because the return on assets is formed under the influence of all activities.

The normative value of the debt-to-equity ratio is in the range of 0.4-0.6. A lower value can mean the high level of financial risks. The value above 0.6 means that enterprise does not use its full potential. It is possible to compare debt-to-equity ratio with competitors of the same size. For different industries, the normative value will vary. For example, for commercial banks, the value is 0.05 or less. For new companies that have not yet proven themselves on the market, debt-to-equity ratio is high. The negative value indicates a rapid bankruptcy, and actions to restore financial sustainability should be applied immediately.

As it can be seen, none of the indicators for assessment of the enterprise bankruptcy has a universal normative value. Each of them is inaccurate and ambiguous, depending on the field of activity, industry, enterprise life cycle, level of competition, season. The theory of fuzzy sets has proved its efficiency for the formalization of undefined boundaries indicators.

When describing fuzzy sets, the membership function plays the key role, since all operations with fuzzy objects are reduced to actions with their membership functions.

Justifying the membership function of fuzzy sets is one of the most important questions of the methodology, which must be started from defining the scope of reasoning (universe of discourse). For example, bankruptcy high risk for the current ratio is limited within $[0.25 ; 1.5]$.

Methods for constructing the membership function can be divided into direct and indirect.

When using direct methods, an expert (or a group of experts) independently determines the rules for evaluating the values of the membership function for indicators of bankruptcy risk assessment. The value of the empirical function of determination is calculated by the formula:

$$
\mu_{A}(x)=\frac{n_{+}(x)}{N}
$$

where $n_{+}(x)$ is the number of experts who gave a positive answer to the question about the belonging of the element $x$ to the set $A$.

For example, a group of 5 experts makes a judgment for the current ratio. The question is formulated as follows: "What value of the current ratio indicates a high risk of bankruptcy?"

The experts' answers are summarized in the table. 
Table 1. Experts answers to a question: "What value of the current ratio indicates a high risk of bankruptcy?"

Source: Compiled by the authors.

\begin{tabular}{l|c:c:c:c:c:c}
\hline \multicolumn{1}{c}{ Expert } & $\mathbf{0 . 2 5}$ & $\mathbf{0 . 5}$ & $\mathbf{0 . 7 5}$ & $\mathbf{1}$ & $\mathbf{1 . 2 5}$ & $\mathbf{1 . 5}$ \\
\hline 1 & 1 & 1 & 1 & 1 & 0 & 0 \\
\hdashline 2 & 1 & 1 & 0 & 0 & 0 & 0 \\
\hdashline 3 & 1 & 1 & 1 & 1 & 1 & 0 \\
\hdashline 4 & 1 & 1 & 1 & 1 & 0 & 0 \\
\hdashline 5 & 1 & 1 & 1 & 1 & 1 & 0 \\
\hdashline$n_{+}(x)$ & 5 & 5 & 4 & 4 & 2 & 0 \\
\hdashline$\mu_{A}(x)$ & 1 & 1 & 0.8 & 0.8 & 0.4 & 0 \\
\hline
\end{tabular}

The result is a formalized fuzzy function $A^{1}=$ "current ratio indicates a high risk of bankruptcy" in the form:

$$
A^{1}=\frac{1}{0.25}+\frac{1}{0.5}+\frac{0.8}{0.75}+\frac{0.8}{1}+\frac{0.4}{1.25} .
$$

Similarly, the formalized fuzzy function $A^{2}$ is defined. $A^{2}=$ "current ratio indicates a low risk of bankruptcy":

$$
A^{2}=\frac{0.2}{1}+\frac{0.6}{1.25}+\frac{1}{1.5}+\frac{1}{1.75}+\frac{0.6}{2} .
$$

For the rest of the system of indicators for assessment of the enterprise bankruptcy probability the same examination is conducted.

A set of classifiers of current values of indicators is formed. It includes current ratio, payable turnover ratio, equity turnover ratio, return on assets, debt-to-equity ratio, as criteria for dividing the full set of their values into fuzzy subsets of two types: low risk of bankruptcy and high risk of bankruptcy. In this case, the cells of the table are numbers that characterize the corresponding membership functions. If the coefficient falls into both groups, then it is necessary to choose the one for which the value of the membership function is higher. For example, for current ratio, according to most experts, a value of 1 is more suitable for a high bankruptcy risk than a low one.

Thus, there is a suggestion that for some conditional enterprise the membership functions were built, presented in Table 2.
Table 2. Classification of financial indicators

Source: Compiled by the authors

\begin{tabular}{c|c|c}
\hline Ratio & “Low" & “High" \\
\hline Current ratio & $(1.25 ; 1.5 ; 1.75 ; 2)$ & $(0.25 ; 0.50 .75 ;$ \\
& $1.0)$ \\
\hline Payable turnover ratio & $(6.5 ; 7.0 ; 7.5 ; 8.0)$ & $(8.5 ; 9.0 ; 9.5)$ \\
\hline Equity turnover ratio & $(2.0 ; 3.0 ; 4.0 ; 5.0)$ & $(6.0 ; 7.0 ; 8.0 ; 9 ; 0)$ \\
\hline Return on assets & $(7.0 ; 8.0 ; 9.0 ;$ & $(12.0 ; 13.0 ; 14.0)$ \\
\hline Debt-to-equity ratio & $10.0 ; 11.0)$ & $(0.3 ; 0.4)$ \\
\hline
\end{tabular}

Next, recognition of the current values of the indicators is performed according to the criterion of the table of type 2. Recognition of the level of the indicator is the most controversial question of this method. This procedure is entirely depends on the expert's judgement, based on his experience.

If a column of values of indicators for the enterprise (conditional values) is added to the table, then the obtained matrix representation is the result of modeling sufficient to assess the risk of bankruptcy of the enterprise.

Table 3. System of indicators for assessment of the conditional enterprise bankruptcy probability

Source: Compiled by the authors.

\begin{tabular}{l|c:c:c}
\hline \multicolumn{1}{c}{ Ratio } & Value & "Low" & "High" \\
\hline Current ratio & 1.45 & 1 & 0 \\
\hline Payable turnover ratio & 9.15 & 0 & 1 \\
\hdashline Equity turnover ratio & 3.6 & 1 & 0 \\
\hline Return on assets & 10.3 & 1 & 0 \\
\hline Debt-to-equity ratio & 0.5 & 0 & 0 \\
\hline
\end{tabular}

Hence the linguistic recognition of the degree of risk according to Table 2 gives a low risk of bankruptcy.

Visualization of the proposed approach requires the normalization of the values of each financial indicator, which can be calculated according to the formula:

$$
\tilde{x}=\frac{x_{i}-x_{\min }}{x_{\max }-x_{\min }},
$$

where $x_{i}$ is the calculated value of the $i$-th indicator, $x_{\min }$ - the minimum value of the fuzzy subset "low risk of bankruptcy", $x_{\max }$ - the maximum value of the fuzzy subset "low risk of bankruptcy".

A similar formula is used for the fuzzy subset of "high bankruptcy risk". 


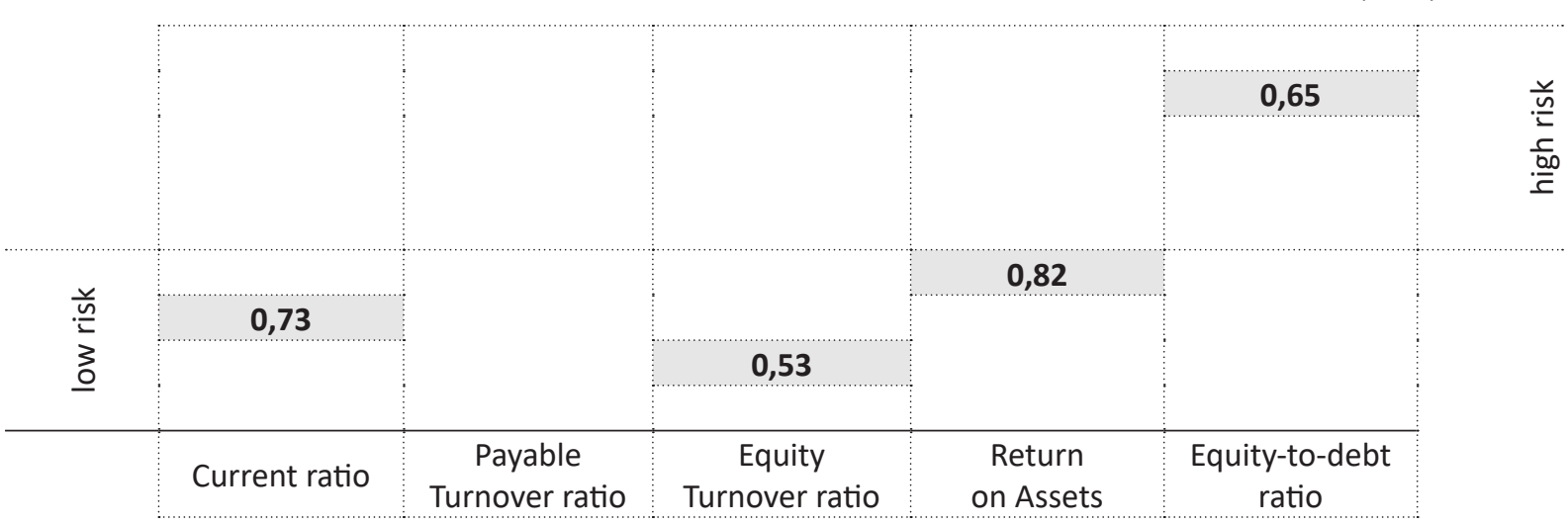

Figure 1. The matrix of normalized values of indicators for assessment of the conditional enterprise bankruptcy probability

The convenience of using this formula is conditioned by the fact that if the normalized index is greater than 1 or less than 0 , then it belongs to another zone.

Visualization can be performed in the form of a linear or dotted graphics in different zones of fuzzy sets or simultaneously in several zones, as well as in the form of a matrix.

For the conditional example presented in Table 3, the matrix of normalized values calculated by the proposed formula can be represented as follows (Figure 1).

The advantages of the proposed visualization approach are the following:

- the simple justification of a fuzzy function by experts who are well aware of the enterprise's and the industry's specifics;
- the ability to break financial performance into the required number of fuzzy subsets;

- the rejecting the convolution formulas use for indicators for assessment of the enterprise bankruptcy probability, thereby ensuring the correctness of the model.

Using various ways to visualize the results obtained allows an expert formalizing fuzzy ideas in the best way, transforming the language of words into a language of quantitative assessments.

Based on the results of the above studies, a decision support system (DSS) is offered to administer and implement a comprehensive bankruptcy probability assessment system for Ukrainian enterprises. This decision support system for assessing the probability of bankruptcy of Ukrainian enterprises is based on the fuzzy set theory (Kozlovskyi et

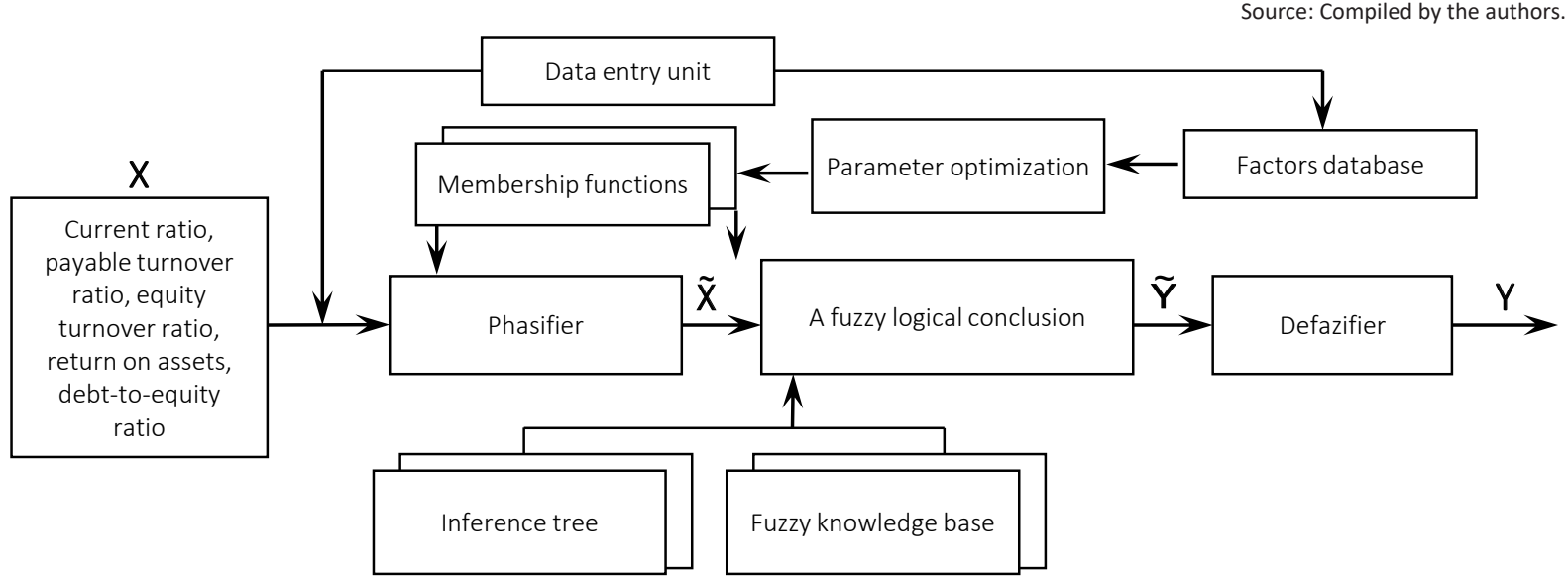

Figure 2. Decision support system for assessing the probability of bankruptcy of enterprises 
al., 2018; Fonitska, 2013), and also takes into account such indicators of International Financial Reporting Standards as: current ratio, payable turnover ratio, equity turnover ratio, return on assets, debt-to-equity ratio.

The structure of this decision support system for bankruptcy assessment is shown in Figure 2 .

The developed system of making and supporting decisions on the assessment of bankruptcy probability allows determining the level of bankruptcy of Ukrainian enterprises according to the indicators of International Financial Reporting Standards and analyzing its dynamics. DSS enables business entities to respond in a timely and adequate manner to possible changes in an entity's financial and economic activities and to make appropriate management decisions.

\section{DISCUSSION}

This study showed that the following ideas should be considered to solve the problem of qualitative assessment of bankruptcy probability of Ukrainian enterprises:

1. The system of indicators for assessment of the enterprise bankruptcy probability fully complies with International Financial Reporting Standards and includes following indicators: current ratio, payable turnover ratio, equity turnover ratio, return on assets, debt-to-equity ratio. Use of this system allows foreign investors to assess the enterprise bankruptcy probability, taking into account the Ukrainian economy specifics.

2. Financial indicators classification of system for assessment of the enterprise bankruptcy probability was made (Table 2). Based on expert's subjective judgment, financial indicators classification allows considering expert's knowledge about the enterprise, its environment and various risk factors. The need to use theory of fuzzy sets is due to the fact that each indicator is inaccurate and ambiguous, depending on internal and external factors. Formalizing expert's fuzzy ideas from the language of words into a language of quantitative assessments simplifies understanding the results of the bankruptcy probability.

3. Because of the fact that the visualization of the proposed approach requires the normalization of the values of each indicator for assessment of the enterprise bankruptcy probability, a corresponding formula was offered (formula 1). Using the formula, a matrix of normalized values of indicators for assessment of the conditional enterprise bankruptcy probability was created (Figure 1). Suggested visualization approach of indicators for assessment of the enterprise bankruptcy allows building an enterprise financial card without using complex financial indicators.

4. As an example, for a system of indicators for assessment of the conditional enterprise bankruptcy probability linguistic risk recognition was done. The given example clearly demonstrates the possibilities of applying the method of the enterprise bankruptcy assessment on the basis of intellectual analysis. The example makes it possible to use the method in practice by both foreign investors to assess the enterprise bankruptcy probability and by internal auditors.

5. The structure of decision support system for bankruptcy probability assessment of the enterprise with the help of fuzzy set theory was constructed.

\section{CONCLUSION}

Studies have shown that existing classical methods of assessment of the enterprise bankruptcy probability cannot be fully applied in practice and used in making decisions. The most well-known models of the assessment of the enterprise bankruptcy such as Altman, Toffler, Tishaw models are based on quantitative indicators and do not allow doing verification of the obtained values. An attempt to consider the qualitative indicators in the enterprise bankruptcy was made by Ukrainian scientist Matviychuk, but this model is based only on the financial statements of Ukraine. 
Improvement of Matviychuk model is based on the theory of fuzzy sets and takes into account the International Financial Reporting Standards. It allows operating both quantitative and qualitative indicators simultaneously, and using the indicators of International Financial Reporting Standards such as current ratio, payable turnover ratio, equity turnover ratio, return on assets, debt-to-equity ratio that applied in world practice. Proposed model solves the problematic issues that are the disadvantages of the assessment of the enterprise bankruptcy probability classic models and allows performing the procedure of assessing the enterprise economic activity with a high level of probability. In addition, it helps make the correct management decisions.

The obtained scientific result will greatly facilitate the work of specialists and managers in the field of assessing bankruptcy of enterprises and make it possible to better assess the likelihood of bankruptcy of an enterprise both in the domestic and international markets.

\section{REFERENCES}

1. Altman, E. (1968). Financial Ratios, Discriminant Analysis and the Prediction of Corporate Bankruptcy. The Journal of Finance, 23(4), 589-609. https://doi. org/10.2307/2978933

2. Altman, E. (1984). A Further Empirical Investigation of the Bankruptcy Cost Question. The Journal of Finance, 39(4), 1067-1089. https://doi.org/10.2307/2327613

3. Andrushshak, Ye. M. (2004). Діагностика банкрутства українських підприємств [Diahnostyka bankrutstva ukrainskykh pidpryiemstv]. Finansy Ukrainy, 9, 118-124.

4. Barsotti, F., Mancino, E. M., \& Pontier, M. (2016). Switching tax structure and payouts in endogenous bankruptcy models. An International Journal of Probability and Stochastic Processes, 88(2), 163-190. Retrieved from https://www.tandfonline.com/doi/abs/10.1080/1744 2508.2015.1046874

5. Beaver, W., \& Manegold, J. (1975). The Association between MarcetDetermined and Accounting Measured of Systematic Risk Some Futher Evidence. Journal of Financial and Quantitative Analysis, 10(2), 231-284. https:// doi.org/10.2307/2979035

6. Beermann, K. (1976). Prognosemöglichkeiten von Kapitalverlusten mit Hilfe von Jahresabschlüssen. Westfälischen Wilhelms-Universität
Münster, 11, 118-121. Retrieved from https://books. google.com.ua/books/about/ Prognosem\%C3\%B6glichkeiten von_Kapitalverlus. html?id=sKjzngEACAAJ\&redir esc $=\mathrm{y}$

7. Chrystal, M. (2019). Creating a path out of bankruptcy through action learning. Action Learning: Research and Practice, 16(1), 62-67. https://doi.org/10.1080/14767333. 2019.1562695

8. Davidova, G., \& Belikov, A. (1999). Методика количественной оценки риска банкротства предприятий [Metodika kolichestvennoy otsenki riska bankrotstva predpriyatiy]. Upravlenie riskami, 3, 13-20.

9. Dontsova, L., \& Nikiforova, N. (2015). Анализ бухгалтерской (финансовой) отчетности [Analiz bukhgalterskoy (finansovoy) otchetnosti]. Moscow: Delo i Servis.

10. Fonitska, T., \& Kozlovskyi, S. (2013). Modern theoretical and methodological approaches to the budget management system forming. Economic AnnalsXXI, 3-4, 35-37. Retrieved from https://www.researchgate.net/ publication/291173931_Modern_theoretical_and_methodological_approaches_to_the_budget_management_system_forming

11. Gavurova, B., Packova, M., Misankova, M., \& Smrcka, L. (2017). Predictive potential and risks of selected bankruptcy prediction models in the Slovak business environment. Journal of Business Economics and Management, 18(6), 1156-1173. https://doi.org/10.3846 /16111699.2017.1400461

12. Haider Mohammed Ali Bani Ata (2019). Addressing financial bankruptcy from the Islamic perspective. Banks and Bank Systems, 14(3), 9-19. https://doi. org/10.21511/bbs.14(3).2019.02

13. Kim, S. Y. (2011). Prediction of hotel bankruptcy using support vector machine, artificial neural network, logistic regression, and multivariate discriminant analysis. The Service Industries Journal, 31(3), 441-468. https://doi. org/10.1080/02642060802712848

14. Kozlovskyi, S., Mazur, H., Vdovenko, N., Shepel, T., \& Kozlovskyi, V. (2018). Modeling and forecasting the level of state stimulation of agricultural production in Ukraine based on the theory of fuzzy logic. Montenegrin Journal of Economics, 14(3), 37-53. Retrieved from https://www.researchgate.net/ publication/327144209_Modeling and_Forecasting_the_Level_of_ State_Stimulation_of_Agricultural_Production_in_Ukraine_Based_ on_the_Theory_of_Fuzzy_Logic

15. Law of Ukraine "Code of Ukraine on Bankruptcy Procedures", No. 19, 2597-VIII, October 18, 2018. Retrieved from https://zakon.rada.gov.ua/laws/ show/2597-19 
16. Ligonenko, L. (2016)

Антикризове управління підприємством в умовах економіки знань та інтелектуалізації менеджменту [Antykryzove upravlinnia pidpryiemstvom $\mathrm{v}$ umovakh ekonomiky znan ta intelektualizatsii menedzhmentu]. Ekonomichnyi forum, 1, 161-170. Retrieved from http://www.irbis-nbuv.gov.ua/ cgi-bin/irbis_nbuv/cgiirbis_64.ex $\mathrm{e}$ ? I21DBN=LINK\&P21DBN=U $J R N \& Z 21 \mathrm{ID}=\& S 21 \mathrm{REF}=10 \& S 2$ $1 \mathrm{CNR}=20 \& S 21 \mathrm{STN}=1 \& \mathrm{~S} 21 \mathrm{FM}$ $\mathrm{T}=\mathrm{ASP} \_$meta\&C21COM$=\mathrm{S} \& 2$ $\mathrm{S} 21 \mathrm{P} 03=\mathrm{FILA}=\& 2$ S21STR=ecfor $\_2016 \_1 \_25$

17. Lukason, O., \& Käsper, K. (2017). Failure prediction of government funded start-up firms. Investment Management and Financial Innovations, 14(2-2), 296-306. https:// doi.org/10.21511/imfi.14(22).2017.01

18. Matviychuk, A. (2013). Bankruptcy prediction in transformational economy: discriminant and fuzzy logic approaches. Fuzzy economic review, $X V(1), 21-38$. Retrieved from https://ideas.repec.org/a/fzy/ fuzeco/vxvy2010i1p21-38.html

19. Matviychuk, A. (2013). Нечіткі, нейромережеві та дискримінантні моделі діагностування можливості банкрутства підприємств [Nechitki, neiromerezhevi ta dyskryminantni modeli diahnostuvannia mozhlyvosti bankrutstva pidpryiemstv]. Neiro-nechitki tekhnolohii modeluivannia $v$ ekonomitsi, 2, 71-118. Retrieved from http://www.irbis-nbuv.gov. ua/cgi-bin/irbis_nbuv/cgiirbis_64. exe? $21 \mathrm{DBN}=\mathrm{LINK} \& \mathrm{P} 21 \mathrm{DBN}=$ UJRN\&Z21ID $=\& S 21 \mathrm{REF}=10 \& S$ $21 \mathrm{CNR}=20 \& S 21 \mathrm{STN}=1 \& \mathrm{~S} 21 \mathrm{FM}$ $\mathrm{T}=\mathrm{ASP} \_$meta\&C21COM=S\&2 $\mathrm{S} 21 \mathrm{P} 03=\mathrm{FILA}=\& 2$ S21STR=Nntm_2013_2_6

20. Obradović, D. B., Jakšić, D., Rupić I. B., \& Andrić, M. (2018). Insolvency prediction model of the company: the case of the Republic of Serbia. Economic ResearchEkonomska Istraživanja, 31(1), 139-157. https://doi.org/10.1080/1 331677X.2017.1421990
21. Robbins, T. R., Zemanek, J. E., \& Jr. (2017), UFC pay-per-view buys and the value of the celebrity fighter. Innovative Marketing, 13(4), 35-46. https://doi.org/10.21511/ im.13(4).2017.04

22. Sayfullin, R., \& Kadykov, G. (2003) Прогнозирование банкротства с использованием факторных моделей [Prognozirovanie bankrotstva s ispolzovaniem faktornykh modeley]. Ekonomika $i$ zhizn, 41, 11 .

23. Schwarz, J., \& Pospisil, M. (2018). Bankruptcy, Investment, and Financial Constraints: Evidence from the Czech Republic. Eastern European Economics, 56(2), 99121. https://doi.org/10.1080/00128 775.2017 .1407221

24. Serrano-Cinca, C., FuertesCallén, Y., Gutiérrez-Nieto, B., \& Cuellar-Fernández, B. (2014). Path modelling to bankruptcy: causes and symptoms of the banking crisis. Applied Economics, 46(31), 3798-3811. https://doi.org/10.1080 /00036846.2014.943882

25. Sharapov, O., \& Kaidanovich, D. (2012). Оцінювання можливого банкрутства на основі індикаторів фінансового стану компаній з використанням нейронних мереж зустрічного розповсюдження [Otsiniuvannia mozhlyvoho bankrutstva na osnovi indykatoriv finansovoho stanu kompanii $z$ vykorystanniam neironnykh merezh zustrichnoho rozpovsiudzhennia]. Neiro-nechitki tekhnolohii modeliuvannia $v$ ekonomitsi, 1, 207-227. Retrieved from http://nbuv.gov.ua/UJRN/ Nntm_2012_1_1

26. Tereshenko, O. (2003). Дискримінантна модель інтегральної оцінки фінансового стану підприємства [Dyskryminantna model intehralnoi otsinky finansovoho stanu pidpryiemstva]. Ekonomika Ukrainy, 8, 38-44. Retrieved from http://liber.onu.edu.ua/opacunicode/index.php?url=/notices/index/IdNotice:73956/Source:default

27. Toffler, R., \& Tishaw, H. (1977). Going, going, gone - four factors which predict. Accountancy, 88, 50-54. Retrieved from http://www. oalib.com/references/13115775
28. Wakkee, I., Dorrestein, F., \& Englis, P. (2014). The stigmatization of bankrupt entrepreneurs in Dutch newspapers. Journal of Small Business \& Entrepreneurship, 27(4), 369-391. https://doi.org/10.1080/0 8276331.2015.1017869

29. Yousuf, A., Haddad, H., Pakurar, M., Kozlovskyi, S., Mohylova, A., Shlapak, O., \& Janos, F. (2019). The effect of operational flexibility on performance: a field study on small and medium-sized industrial companies in Jordan. Montenegrin Journal of Economics, 15(1), 47-60. Retrieved from https://ideas.repec.org/a/mje/mjejnl/v15y2019i1p47-60.html

30. Yu, K., \& He, D. (2018). The choice between bankruptcy liquidation and bankruptcy reorganization: a model and evidence. Journal of Management Analytics, 5(3), 170197. https://doi.org/10.1080/23270 012.2018.1462112

31. Zadeh, L. (1965). Fuzzy Sets. Information and Control, 8(3), 338-353. https://doi.org/10.1016/ S0019-9958(65)90241-X

32. Zavadskyi, I., Osovska, T., \& Yushkevych, O. (2006). Економічний словник [Ekonomichnyi Slovnyk]. Kyiv: Kondor. 